\title{
THE RELATIONSHIP BETWEEN NUMBERS OF SPERMATOZOA INSEMINATED AND \\ FERTILIZATION RATE OF OVA IN EWES TREATED WITH FLUORO-PROGESTAGEN INTRAVAGINAL SPONGES IN SUMMER AND AUTUMN
}

\author{
T. D. QUINLIVAN* \\ Department of Animal Husbandry, University of Sydney, \\ Sydney, N.S.W., 2006
}

(Received 30th September 1969)

Summary. Two experiments were conducted, during December and March, designed primarily to determine the oestrous response and fertilization rate following the insemination of varying numbers of spermatozoa in ewes treated with intravaginal sponges impregnated with Cronolone, a synthetic progestagen. The main results were:

1. Incidence of oestrus: December; (a) treated ewes, $45.7 \%$; (b) untreated teased ewes, $47.5 \%$; (c) untreated non-teased ewes, $30.0 \%$; March; (d) treated ewes, $94.8 \%$ (a versus b, NS; a versus c, $P<0.01$; a versus $\mathrm{d}, P<0.001)$.

2. Peak incidence of oestrus after withdrawal of sponges: December, $72 \mathrm{hr}$; March, $48 \mathrm{hr}(P<0.001)$.

3. Overall percentage of ewes which yielded fertilized ova: December, 64.3; March, 83.2 $(P<0.001)$.

4. Numbers of spermatozoa and fertilization in treated ewes: December, linear increase in percentage of ewes fertilized, with increasing sperm numbers, from $44.0 \%\left(300 \times 10^{6}\right.$ spermatozoa) to $76.0 \%(1500 \times$ $10^{6}$ spermatozoa); March, no effect of numbers of spermatozoa, with $83.2 \%$ ova fertilized (100 to $1500 \times 10^{6}$ spermatozoa).

5. Number of spermatozoa and fertilization in untreated versus treated ewes: December $\left(300 \times 10^{6}\right.$ spermatozoa $)$; untreated, $43.3 \%$, treated $44.0 \%$ (NS); March (100 to $1500 \times 10^{6}$ spermatozoa); untreated $78.8 \%$, treated $83.2 \%$ (NS).

6. Effect of breed of ram on percentage of treated ewes fertilized in December: Merino, 75.6\%, Border Leicester, $47.5 \%(P<0.001)$. Similar differences were observed in untreated ewes.

7. In both December and March, $21.4 \%$ of fertilized ova showed unequal cleavage or anuclear fragmentation.

* Present address: N.Z. Romney Survey, Box 231, Feilding, New Zealand. 
8. The estimated mean numbers of spermatozoa recovered from the Fallopian tubes of progestagen-treated and untreated ewes $24 \mathrm{hr}$ after the insemination of $300 \times 10^{6}$ spermatozoa were 807 and $5019(P<$ $0 \cdot 001)$.

\section{INTRODUCTION}

Quinlivan \& Robinson $(1967,1969)$ have shown an alteration in the pattern of transport and survival of spermatozoa throughout the genital tract of the ewe at the first synchronized oestrus following withdrawal of intravaginal sponges impregnated with the synthetic progestagen $17 \alpha$-acetoxy- $9 \alpha$-fluoro$11 \beta$-hydroxypregn-4-ene-3,20-dione (Cronolone, Searle; Robinson, 1965 ; Shelton, 1965). This work also demonstrated that the insemination of numbers of spermatozoa within the range 80 to $500\left(\times 10^{6}\right)$ had no discernible effect on the numbers recovered from the Fallopian tubes 4, 12, 24 and $36 \mathrm{hr}$ after insemination, or on the fertilization rate of ova.

However, on the basis of extensive field work using semen of differing qualities and dilutions, Robinson (1967) considered that an increase in the number of spermatozoa inseminated, far in excess of normal requirements, may lead to a subsequent improvement in conception rate. Two experiments were designed to test this hypothesis, the first during the early summer, in ewes which had all lambed 3 months previously, and the second 3 months later during the breeding season.

The experiments were conducted at the McCaughey Memorial Institute, Jerilderie, N.S.W., in December 1966 and March 1967.

\section{MATERIALS AND METHODS}

\section{Experimental animals}

In Exp. 1, 1200 Merino ewes, 5 years old, plus eleven Merino and fourteen Border Leicester rams and three vasectomized rams were used. All ewes had lambed 3 to 4 months previously.

In Exp. 2, 350 Merino ewes, 4 years old, eleven Merino rams and twenty vasectomized rams were used.

\section{Experimental design}

In Exp. 1, the 1200 ewes were randomized into two flocks, Flock 1 of 960 ewes and Flock 2 of 240. All ewes of Flock 1 were treated with impregnated sponges, while those of Flock 2 were untreated. One half of Flock 2 was exposed to vasectomized rams 6 weeks before the experiment (120 'teased ewes'). The remaining ewes were not so exposed (120 'unteased').

The two flocks were used in the following four tests. Tests 1 and 2 measured the incidence of oestrus while 3 and 4 measured the percentage of fertilized eggs recovered.

Test 1. Flock 1 only. Effect of duration of insertion of sponges on incidence of oestrus in Merino ewes in early summer: 480 ewes were treated for 12 days and 480 for 16 days. The numbers of ewes served were recorded.

Test 2. Flocks 1 and 2. Effect of teasing and of intravaginal sponges on the incidence of oestrus in Merino ewes in early summer: 960 treated ewes were 
compared with 120 untreated 'teased', and 120 untreated 'unteased' ewes. The numbers of ewes served over a 20 -day period were recorded, commencing on the day of sponge withdrawal.

Test 3. Flock 1 only. Effect of duration of insertion of sponges, breed of ram, and numbers of spermatozoa on percentage of ewes fertilized: 360 ewes, 180 treated for 12 days and 180 for 16 days, were incorporated into a factorial test:

Duration of insertion

- 12 versus 16 days

Breed of ram

- Merino versus Border Leicester

Number of spermatozoa $\left(\times 10^{6}\right)-300,600,900,1200,1500,>1500^{*}$

* Hand service (see p. 91)

$2 \times 2 \times 6 ; \mathrm{h}=15 ; \mathrm{N}=360$.

The numbers of eggs recovered, fertilized and with spermatozoa attached to the zona pellucida, were recorded.

Test 4. Flocks 1 and 2. Effect of intravaginal sponges, compared with no treatment, and of breed of ram on percentage of ewes fertilized: the sixty treated ewes from Flock 1 inseminated with $300 \times 10^{6}$ spermatozoa were incorporated into a factorial test with sixty untreated ewes from Flock 2 inseminated with the same number of spermatozoa from the same rams $(2 \times 2 ; n=30 ; N=$ 120). Data recorded were as for Test 3.

Failure of the Border Leicester rams to produce sufficient semen necessitated a departure from strict orthogonality in Tests 3 and 4 (see appropriate tables of results).

In Exp. 2, the 350 ewes were randomized into two flocks, Flock 3 of 250 ewes and Flock 4 of 100 . All ewes of Flock 3 were treated for 16 days with progestagen-impregnated sponges, while those of Flock 4 were untreated.

The two flocks were used in the following three tests.

Test 1. Flock 3 only. Effect of numbers of spermatozoa on the percentage of ewes fertilized following treatment with intravaginal sponges: 210 oestrous ewes of Flock 3 were inseminated and subsequently ova were recovered at laparotomy. The seven treatments $(n=30)$ were: $100,300,600,900,1200$, $1500,>1500$ spermatozoa.

Test 2. Flocks 3 and 4 . Effect of intravaginal sponges compared with no treatment on percentage of ewes fertilized: the thirty treated ewes from Flock 3 inseminated with $300 \times 10^{6}$ spermatozoa were compared with thirty untreated ewes from Flock 4 inseminated with the same number of spermatozoa $(n=30$, $\mathrm{N}=60$ ).

Data recorded were as for Exp. 1, Tests 3 and 4.

Test 3 . Flocks 3 and 4 . Comparison of numbers of spermatozoa recovered from the Fallopian tubes of treated and untreated ewes $24 \mathrm{hr}$ after insemination: twenty oestrous ewes of Flock 3 and twenty of Flock 4 were inseminated with $300 \times 10^{6}$ spermatozoa; $24 \mathrm{hr}$ later, the Fallopian tubes were flushed for the recovery of spermatozoa $(n=20, N=40)$.

\section{Management}

In Exp. 1, the ewes were randomized into two flocks on 27th October 1966, when six vasectomized rams fitted with harnesses and crayons were joined with 
the 120 untreated 'teased' ewes. Thereafter, the time schedule shown in Table 1 applied.

In Exp. 2, the ewes were randomized into two flocks on 5th March 1967, when insertion of impregnated sponges commenced at the rate of fifty every $2 n d$ day.

Thereafter, the time schedule shown in Table 2 applied.

TABLE 1

TIME SGHEDULE-EXPERIMENT 1

\begin{tabular}{|c|c|c|c|c|}
\hline \multirow{3}{*}{ Operation } & \multirow{3}{*}{$\begin{array}{l}\text { Date } \\
1966\end{array}$} & Flock 1 & & ck 2 \\
\hline & & \multirow{2}{*}{ Treated } & \multicolumn{2}{|c|}{ Untreated } \\
\hline & & & Teased & Unteased \\
\hline Randomization & Oct. 27 & 960 ewes & 240 ewes & 240 ewes \\
\hline $\begin{array}{l}\text { Vasectomized rams } \\
\text { Vasectomized rams } \\
\text { Vasectomized rams } \\
\text { Vasectomized rams-new raddle }\end{array}$ & $\begin{array}{l}\text { Oct. } 27 \text { to Nov. } 10 \\
\text { Nov. } 11 \text { to Nov. } 23 \\
\text { Nov. } 24 \text { to Dec. } 8 \\
\text { Dec. } 8 \text { to Dec. } 28\end{array}$ & $\begin{array}{l}- \\
-\end{array}$ & $6 \underset{12 \mathrm{rams}}{6 \mathrm{rams}}$ & $=$ \\
\hline Insertion of sponges in batches & Nov. 30 to Dec. 12 & 960 ewes & - & - \\
\hline $\begin{array}{l}\text { Removal of sponges and intro- } \\
\text { duction of twenty-five vasec- } \\
\text { tomized rams to Flock } 1\end{array}$ & $\begin{array}{r}\text { Dec. } 16 \\
18 \\
20 \\
22 \\
24\end{array}$ & $\begin{array}{l}192 \text { ewes } \\
192 \text { ewes } \\
192 \text { ewes } \\
192 \text { ewes } \\
192 \text { ewes }\end{array}$ & $\bar{z}$ & $\begin{array}{l}\bar{z} \\
\bar{z}\end{array}$ \\
\hline $\begin{array}{l}\text { Artificial insemination and hand } \\
\text { service (on detection of oestrus) }\end{array}$ & Dec. 18 to 26 & 360 ewes & 60 & wes \\
\hline
\end{tabular}

TABLE 2

TIME SCHEDULE-EXPERIMENT 2

\begin{tabular}{|c|c|c|c|}
\hline Operation & $\begin{array}{l}\text { Date } \\
1967\end{array}$ & $\begin{array}{l}\text { Flock } 3 \\
\text { Treated }\end{array}$ & $\begin{array}{c}\text { Flock } 4 \\
\text { Untreated }\end{array}$ \\
\hline Randomization & March 5 & 250 ewes & 100 ewes \\
\hline Vasectomized rams & March 22 to 31 & - & 5 rams \\
\hline Insertion of sponges in batches & March 5 to 13 & 250 ewes & - \\
\hline $\begin{array}{l}\text { Removal of sponges and intro- } \\
\text { duction of fifteen vasectomized } \\
\text { rams }\end{array}$ & $\begin{array}{r}\text { March } 21 \\
23 \\
25 \\
27 \\
29\end{array}$ & $\begin{array}{l}50 \text { ewes } \\
50 \text { ewes } \\
50 \text { ewes } \\
50 \text { ewes } \\
50 \text { ewes }\end{array}$ & $\begin{array}{l}= \\
= \\
=\end{array}$ \\
\hline $\begin{array}{l}\text { Artificial insemination and hand } \\
\text { service (on detection of oestrus) }\end{array}$ & March 23 to 31 & 210 ewes & 50 ewes \\
\hline
\end{tabular}

In both experiments, ewes were inspected twice daily for oestrus, at 07.00 and 17.00 hours.

Artificial insemination

All ewes were inseminated once with undiluted semen, as soon as possible after first detection of oestrus. Semen was collected by artificial vagina from 
several animals and pooled. Because of the low volume produced by the Border Leicesters in Exp. 1, collection was from ten rams per pool compared with four for the Merinos.

Each ejaculate was examined for density and motility and only semen of high density and motility was used. The ejaculates were pooled, the number of spermatozoa estimated by haemocytometer counts, and the volumes determined to provide the required numbers of spermatozoa. Counts for the pooled samples were 2.75 to $3.25 \times 10^{9}$ spermatozoa $/ \mathrm{ml}$ for the Border Leicester rams (Exp. 1) and 3.70 to $5.60 \times 10^{9}$ spermatozoa $/ \mathrm{ml}$ for the Merinos (Exps 1 and 2). Estimates of motility and percentage 'normal' and 'abnormal' were comparable for the two breeds, but the volumes differed: Border Leicester, 0.1 to $0.2 \mathrm{ml}$; Merino, 0.6 to $0.9 \mathrm{ml}$.

\section{Hand service}

Each ewe allocated for hand service was served twice-once by each of two rams on which semen checks had been made. By analogy with the sperm counts made on semen samples collected for artificial insemination, the approximate numbers of spermatozoa received per ewe served twice by rams of the two breeds were: Border Leicester, 500 to $1100 \times 10^{6}$; Merino, 4500 to $10,100 \times 10^{6}$.

\section{Recovery of ova}

Ova were recovered in vivo by the method described by Hunter, Adams \& Rowson (1955). Each ovum was mounted and examined under phase contrast microscopy at $\times 200$ to 400 . Cleavage was accepted as the criterion for fertilization. Any ovum that appeared abnormal was cleared in $25 \%$ glacial acetic acid in alcohol and subsequently stained with $1 \%$ natural orcein in $45 \%$ glacial acetic acid.

\section{Hormone treatment}

The polyurethane sponges were $3.5 \mathrm{~cm}$ in diameter and impregnated in the laboratory with $30 \mathrm{mg}$ Cronolone dissolved in $5 \mathrm{ml}$ ethanol. They were suspended from racks, the progestagen in alcohol was injected with a multi-dose automatic syringe, and the sponges were then air dried for $24 \mathrm{hr}$.

Estimates of residual Cronolone were made on eighteen sponges from Exp. 1, and twenty-four from Exp. 2, by the method described by Morgan, Lack \& Robinson (1967), and are shown in Table 3.

\section{TABLE 3}

ESTIMATES OF RESIDUAL CRONOLONE IN INTRAVAGINAL SPONGES INSERTED FOR VARYING LENGTHS OF TIME

\begin{tabular}{c|c|c|c|c}
\hline Experiment & $\begin{array}{c}\text { No. of } \\
\text { sponges } \\
\text { assayed }\end{array}$ & $\begin{array}{c}\text { Duration of } \\
\text { insertion } \\
(\text { days })\end{array}$ & $\begin{array}{c}\text { Mean residual } \\
\text { Cronolone } \\
(\text { mg })^{*}\end{array}$ & $\begin{array}{c}\text { Estimated mean } \\
\text { absorbed } \\
(\mathrm{mg})\end{array}$ \\
\hline \multirow{2}{*}{1} & 6 & 0 & $27 \cdot 9 \pm 2 \cdot 8$ & - \\
& 6 & 12 & $11.9 \pm 7 \cdot 3$ & $16 \cdot 0$ \\
& 6 & 16 & $12 \cdot 2 \pm 4 \cdot 7$ & $15 \cdot 7$ \\
& 12 & 0 & $27 \cdot 5 \pm 4 \cdot 2$ & -7.9 \\
\hline
\end{tabular}

* Within $95 \%$ confidence limits. 
Recovery and counting of spermatozoa

The methods of flushing, counting and statistical analysis were as described by Quinlivan \& Robinson (1967).

\section{RESULTS}

\section{Tests 1 and 2}

EXPERIMENT 1-EARLY SUMMER

Number of ewes which exhibited oestrus. Eight $(0.8 \%)$ of the 960 treated ewes lost sponges. Of the remainder, $439(46.1 \%)$ exhibited oestrus within $120 \mathrm{hr}$ of withdrawal (Table 4). There was no significant effect of duration of treatment on either the total number in oestrus or the time of onset after removal of the sponges.

Over the 21-day period of observations, fifty-seven (47.5\%) of the 120 untreated 'teased' ewes and thirty-six $(30.0 \%)$ of the 120 'unteased' ewes exhibited oestrus $(P<0.01)$.

The oestrous response of the progestagen-treated ewes differed significantly from that of the untreated 'unteased' ewes $(45.7$ versus $30.0 \%, P<0.01)$ but did not differ from that of the 'teased' ewes ( 45.7 versus $47.5 \%$, NS).

\section{Test 3}

Number of progestagen-treated ewes with fertilized ova. The original design of the test called for 360 ewes, 180 inseminated to each of the two breeds. Due to the failure of the Border Leicester rams to produce sufficient semen, the actual numbers used were:

$\begin{array}{lccc}\quad \text { Breed of ram } & \text { Inseminated } & \text { Flushed for ova } & \text { Tielded ova } \\ \text { Merino } & 216 & 208 & 180 \\ \text { Border Leicester } & 144 & 136 & 120 \\ \text { Total } & 360 & 344 & 300\end{array}$

Sufficient ewes of those inseminated were flushed for ova to provide twenty Border Leicester-bred and thirty Merino-bred ewes from which ova were recovered for comparison for each number of spermatozoa used (Table 5, Text-fig. 1). Overall, fifty-seven of 120 ewes $(47.5 \%)$ inseminated with Border Leicester semen were fertilized compared with 136 of $180(75.6 \%)$ inseminated with Merino semen $(P<0.001)$. There was a significant linear effect $(P<$ 0.01 ) of number of spermatozoa $\left(300\right.$ to $\left.1500 \times 10^{6}\right)$, ranging from twenty-two of fifty $(44.0 \%)$ to thirty-eight of fifty $(76.0 \%)$. There was no interaction between breed and number of spermatozoa, and no effect of duration of treatment with progestagen.

Only seven of twenty ewes $(35.0 \%)$ hand mated to Border Leicester rams produced fertilized ova compared with twenty-six of thirty $(86.7 \%)$ mated to Merinos $(P<0.001)$.

Number of ova with spermatozoa attached to the zona pellucida. One hundred and forty-two $(40.7 \%)$ of the 349 ova recovered from the 300 treated ewes had spermatozoa attached to the zona pellucida (Table 6).

There was a highly significant effect of breed of $\operatorname{ram}(P<0.001)$ and a linear effect of numbers of spermatozoa which approached overall significance 


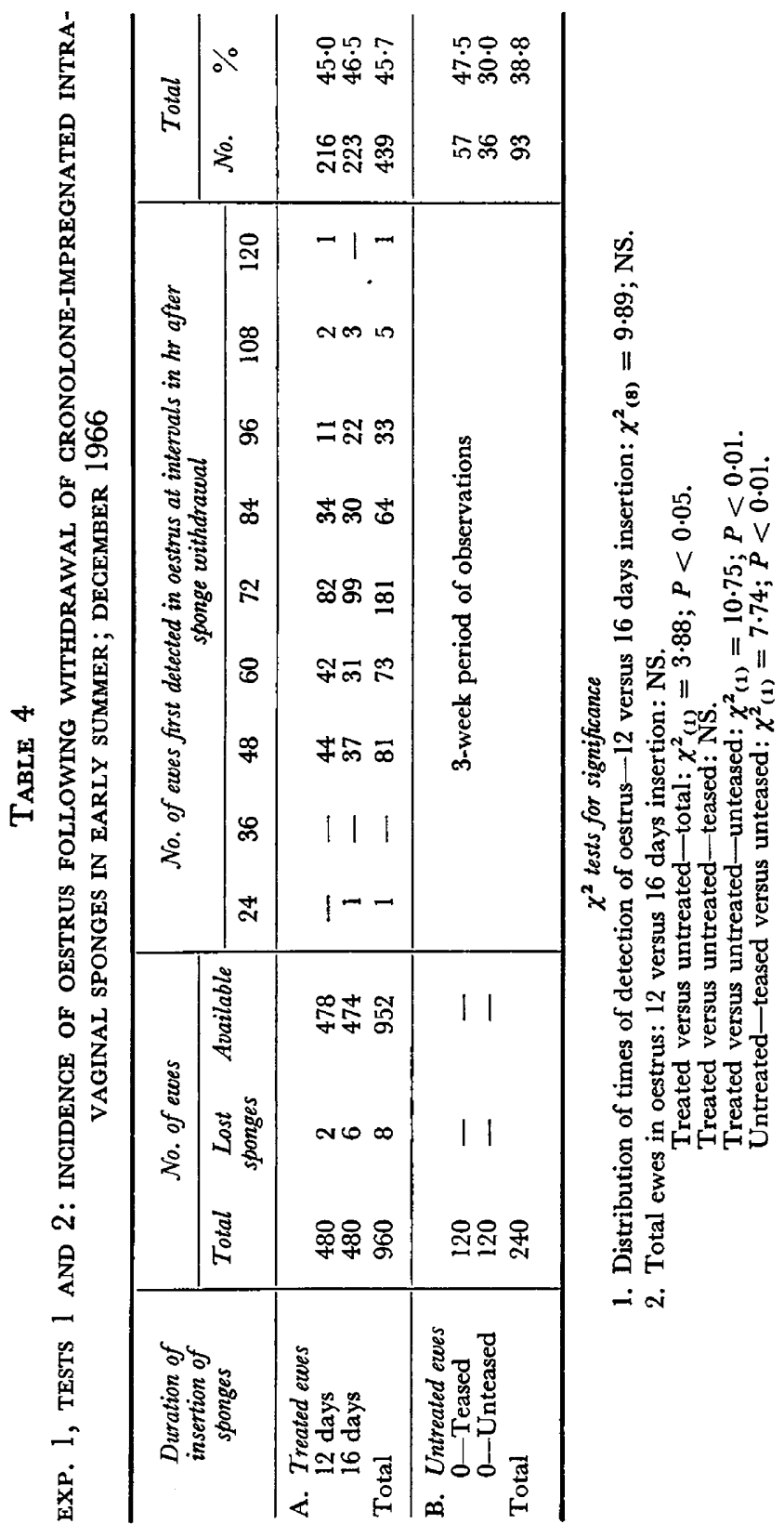




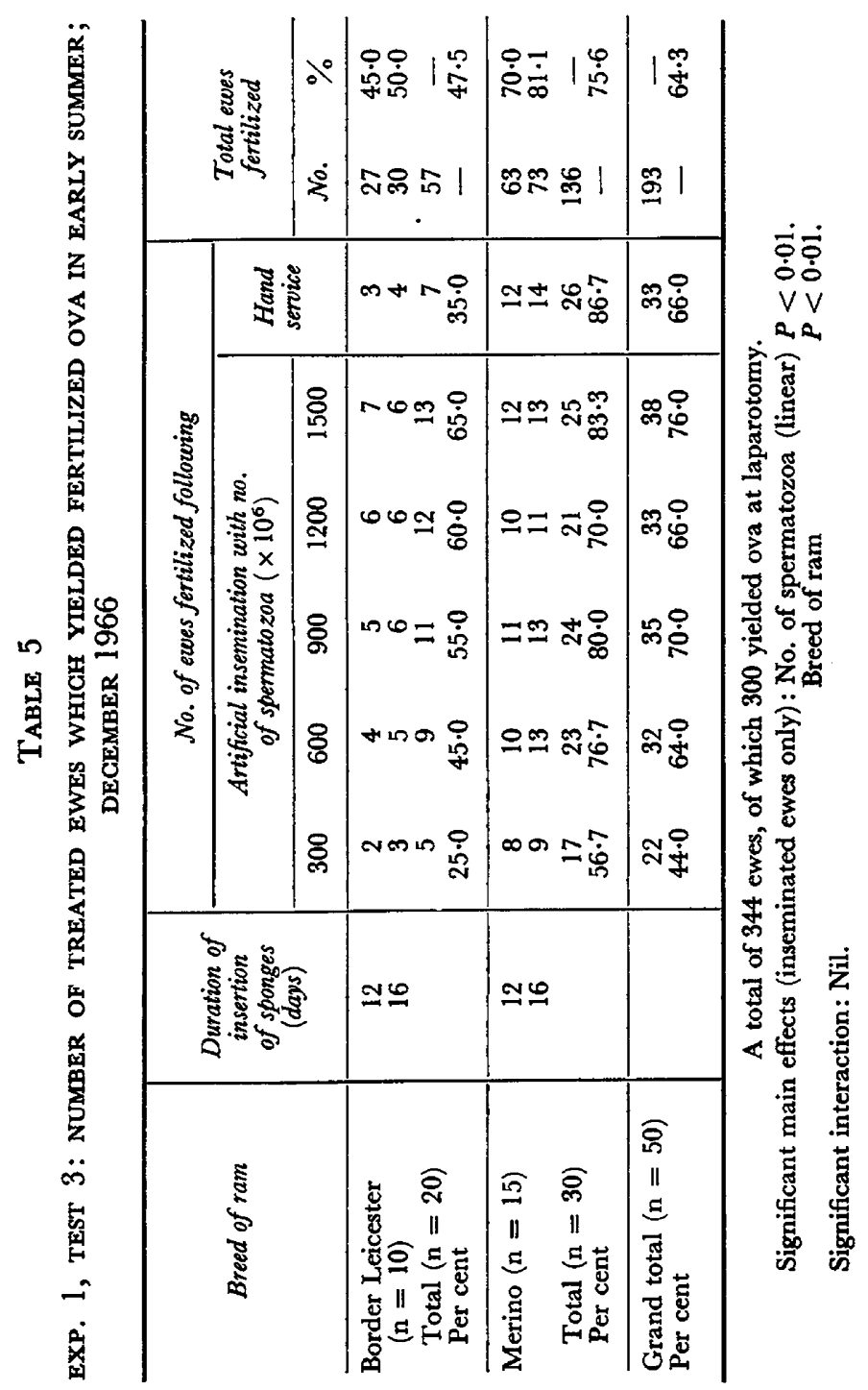



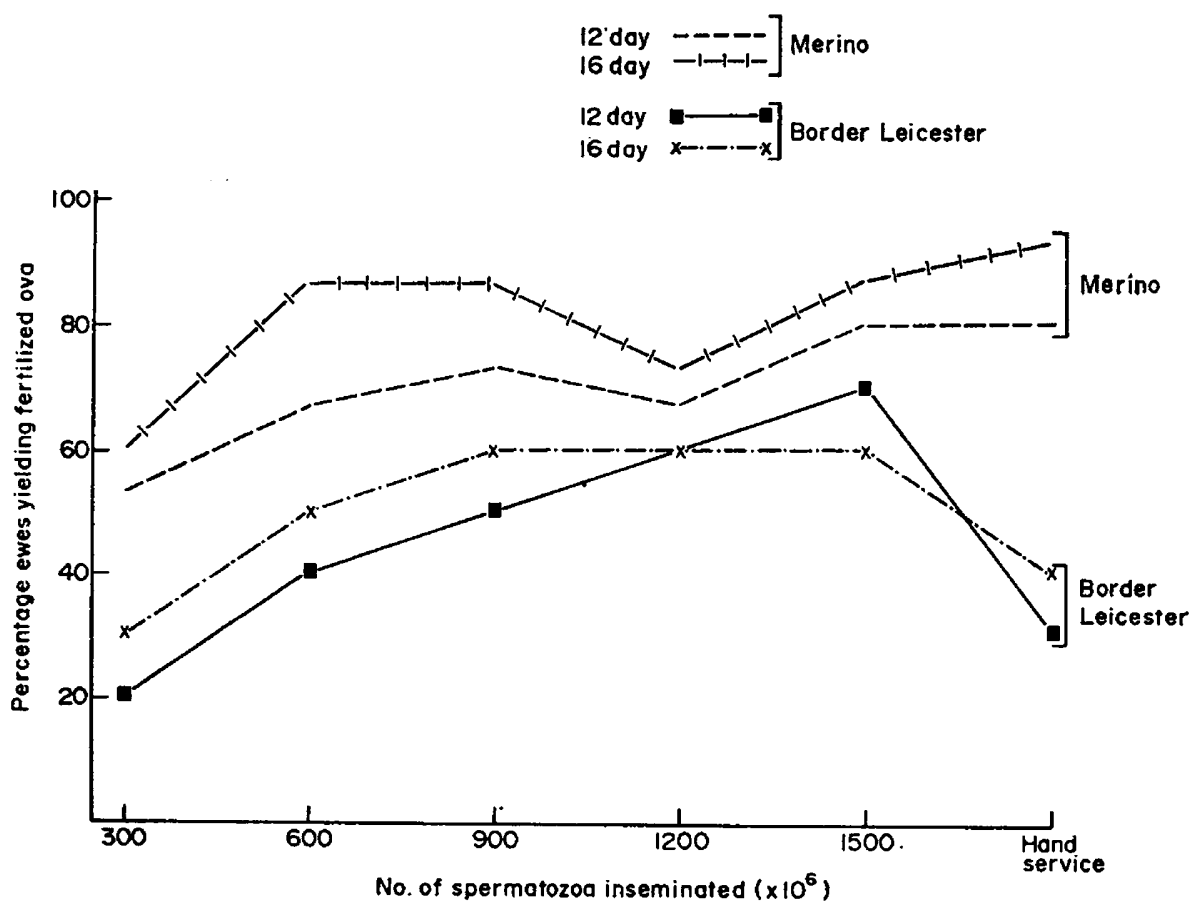

TExT-FIa. 1. Percentage of progestagen-treated ewes which yielded fertilized ova relative to the number of spermatozoa inseminated in early summer-December 1966.

$(0.05<P<0.10)$ and which interacted significantly with breed of ram $(P \fallingdotseq 0.05)$. There was no significant effect of duration of treatment.

Only one of the twenty-five ova recovered from ewes hand served by the

TABLE 6

EXP. 1, TEST 3: NUMBER OF OVA WITH SPERMATOZOA ON THE ZONA PELLUCIDA, FROM EWES TREATED IN EARLY SUMMER; DECEMBER 1966

\begin{tabular}{|c|c|c|c|c|c|c|c|c|}
\hline \multirow[t]{2}{*}{ Breed of ram } & \multirow{2}{*}{$\underset{\text { recovered }}{\text { Ova }}$} & \multicolumn{5}{|c|}{$\begin{array}{l}\text { No. of spermatozoa inseminated } \\
\left(\times 10^{6}\right)\end{array}$} & \multirow{2}{*}{$\begin{array}{l}\text { Hand } \\
\text { service }\end{array}$} & \multirow[t]{2}{*}{ Total } \\
\hline & & 300 & 600 & 900 & 1200 & 1500 & & \\
\hline $\begin{array}{l}\text { Border } \\
\text { Leicester }\end{array}$ & $\begin{array}{l}\text { Total } \\
\text { With sperm. } \\
\%\end{array}$ & $\begin{array}{r}21 \\
5 \\
23 \cdot 8\end{array}$ & $\begin{array}{c}24 \\
7 \\
29 \cdot 2\end{array}$ & $\begin{array}{c}22 \\
7 \\
31 \cdot 8\end{array}$ & $\begin{array}{c}22 \\
5 \\
22 \cdot 7\end{array}$ & $\begin{array}{c}21 \\
6 \\
28 \cdot 6\end{array}$ & $\begin{array}{c}25 \\
1 \\
4 \cdot 0\end{array}$ & $\begin{array}{c}135 \\
31 \\
23 \cdot 0\end{array}$ \\
\hline \multirow[t]{2}{*}{ Merino } & $\begin{array}{l}\text { Total } \\
\text { With sperm. } \\
\%\end{array}$ & $\begin{array}{c}37 \\
10 \\
27 \cdot 0\end{array}$ & $\begin{array}{c}35 \\
16 \\
45 \cdot 7\end{array}$ & $\begin{array}{c}32 \\
19 \\
59 \cdot 4\end{array}$ & $\begin{array}{c}37 \\
21 \\
56 \cdot 8\end{array}$ & $\begin{array}{c}34 \\
21 \\
61 \cdot 8\end{array}$ & $\begin{array}{c}39 \\
24 \\
61 \cdot 5\end{array}$ & $\begin{array}{l}214 \\
111 \\
51 \cdot 9\end{array}$ \\
\hline & $\begin{array}{l}\text { Grand total } \\
\text { With sperm. } \\
\%\end{array}$ & $\begin{array}{c}58 \\
15 \\
25 \cdot 9\end{array}$ & $\begin{array}{c}59 \\
23 \\
39 \cdot 0\end{array}$ & $\begin{array}{c}54 \\
26 \\
48 \cdot 2\end{array}$ & $\begin{array}{c}59 \\
26 \\
44 \cdot 1\end{array}$ & $\begin{array}{c}55 \\
27 \\
49 \cdot 1\end{array}$ & $\begin{array}{c}64 \\
25 \\
39 \cdot 1\end{array}$ & $\begin{array}{l}349 \\
142 \\
40 \cdot 7\end{array}$ \\
\hline
\end{tabular}

The 349 ova were recovered from 300 ewes.

Significant main effects (inseminated ewes only):

No. of spermatozoa (linear) $0.05<P<0 \cdot 10$.

Significant interaction: Number of spermatozoa $\times$ breed $P \fallingdotseq 0.05$.

Breed of ram $P<0.001$. 
Border Leicester rams had spermatozoa attached, compared with twenty-four of thirty-nine of those from Merino matings $(P<0.001)$.

\section{Test 4}

Number of ewes with fertilized ova. Table 7 shows the numbers and percentages of untreated and treated ewes that yielded fertilized ova following insemination with $300 \times 10^{6}$ spermatozoa. There was no effect of treatment but a significant effect of breed of ram $(P<0.01)$.

\section{TABLE 7}

EXP. 1, TEST 4: NUMBER OF PROGESTAGEN-TREATED AND UNTREATED EWES WHICH YIELDED FERTILIZED OVA FOLLOWING INSEMINATION WITH $300 \times 10^{6}$ SPERMATOZOA FROM TWO BREEDS OF RAM IN EARLY SUMMER; DECEMBER 1966

\begin{tabular}{|c|c|c|c|c|c|c|}
\hline \multirow{3}{*}{ Treatment } & \multicolumn{3}{|c|}{ Border Leicester Rams } & \multicolumn{3}{|c|}{ Merino rams } \\
\hline & \multicolumn{2}{|c|}{ No. of ewes } & \multirow{2}{*}{$\begin{array}{c}\% \text { ewes } \\
\text { fertilized }\end{array}$} & \multicolumn{2}{|c|}{ No. of ewes } & \multirow{2}{*}{$\%$ erwes } \\
\hline & $\begin{array}{c}\text { Yielded } \\
\text { ova }\end{array}$ & Fertilized & & $\begin{array}{c}\text { rielded } \\
\text { ova }\end{array}$ & Fertilized & \\
\hline $\begin{array}{l}\text { Progestagen-treated } \\
\text { Untreated }\end{array}$ & $\begin{array}{l}20 \\
15\end{array}$ & $\begin{array}{l}5 \\
4\end{array}$ & $\begin{array}{l}25 \cdot 0 \\
26 \cdot 7\end{array}$ & $\begin{array}{l}30 \\
15\end{array}$ & $\begin{array}{r}17 \\
9\end{array}$ & $\begin{array}{l}56 \cdot 7 \\
60 \cdot 0\end{array}$ \\
\hline Total & 35 & 9 & $25 \cdot 7$ & 45 & 26 & $57 \cdot 8$ \\
\hline
\end{tabular}

The fifty progestagen-treated ewes yielded fifty-eight ova; the thirty untreated ewes yielded thirty-one ova (NS).

Significant main effect: Breed of $\operatorname{ram} P<0.01$.

Seven of the thirty-one ova recovered from the untreated ewes had spermatozoa attached to the zona pellucida as compared with fifteen of the fifty-eight from the fifty treated ewes $(22 \cdot 6$ and $25 \cdot 8 \%$; NS).

\section{Test 1}

\section{EXPERIMENT 2-AUTUMN}

Number of ewes which exhibited oestrus. Three of the 250 progestagen-treated ewes $(1.2 \%)$ lost sponges. Of the remainder, ten $(4.0 \%)$ failed to exhibit oestrus. Thus, $237(94 \cdot 8 \%)$ of the 250 treated ewes exhibited oestrus within $96 \mathrm{hr}$ of withdrawal of sponges (Table 8). Peak onset was $48 \mathrm{hr}$ after removal of the sponges, and $228(96.2 \%$ of oestrous ewes) were served between 36 and $72 \mathrm{hr}$.

\section{TABLe 8}

EXP. 2, TEST 1: INCIDENCE OF OESTRUS FOLLOWING WITHDRAWAL OF GRONOLONE-IMPREGNATED INTRAVAGINAL SPONGES IN AUTUMN; MARCH 1967

\begin{tabular}{l|c|ccccccc|cc|c}
\hline \multirow{2}{*}{$\begin{array}{l}\text { Total } \\
\text { ewes }\end{array}$} & $\begin{array}{c}\text { Lost } \\
\text { sponges }\end{array}$ & \multicolumn{6}{|c|}{$\begin{array}{c}\text { No. of ewes first detected in oestrus at } \\
\text { intervals in hr after sponge withdrawal }\end{array}$} & \multicolumn{3}{|c}{ Total } \\
\cline { 2 - 12 } & 24 & 36 & 48 & 60 & 72 & 84 & 96 & No. & $\%$ \\
\hline 250 & 3 & 2 & 15 & 116 & 73 & 24 & 5 & 2 & 237 & $94 \cdot 8$ \\
\hline
\end{tabular}


Number of ewes with fertilized ova. Ova were recovered from 190 treated ewes of which $158(83.2 \%)$ yielded fertilized eggs (Table 9). There were no significant differences between numbers of spermatozoa or hand service.

TABLE 9

EXP. 2, TEST 1: NUMBER OF TREATED EWES WHICH YIELDED FERTILIZED OVA IN AUTUMN; MARGH 1967

\begin{tabular}{|c|c|c|c|c|c|c|c|c|}
\hline \multirow{2}{*}{$\begin{array}{l}\text { No. of ewes } \\
\text { which yielded: }\end{array}$} & \multicolumn{6}{|c|}{ No. of spermatozoa inseminated $\left(\times 10^{6}\right)$} & \multirow{2}{*}{$\begin{array}{l}\text { Hand } \\
\text { service }\end{array}$} & \multirow[t]{2}{*}{ Total } \\
\hline & 100 & 300 & 600 & 900 & 1200 & 1500 & & \\
\hline $\begin{array}{l}\text { Ova } \\
\text { Fertilized ova }\end{array}$ & $\begin{array}{l}27 \\
23\end{array}$ & $\begin{array}{l}27 \\
24\end{array}$ & $\begin{array}{l}28 \\
25\end{array}$ & $\begin{array}{l}25 \\
18\end{array}$ & $\begin{array}{l}27 \\
22\end{array}$ & $\begin{array}{l}28 \\
24\end{array}$ & $\begin{array}{l}28 \\
22\end{array}$ & $\begin{array}{l}190 \\
158\end{array}$ \\
\hline$\%$ ewes fertilized & $85 \cdot 2$ & $88 \cdot 9$ & $89 \cdot 3$ & $72 \cdot 0$ & $81 \cdot 5$ & $85 \cdot 7$ & $78 \cdot 6$ & $83 \cdot 2$ \\
\hline
\end{tabular}

A total of 210 ewes, of which 190 yielded ova at laparotomy.

Number of ova with spermatozoa attached to the zona pellucida. One hundred and forty-five $(64 \cdot 2 \%)$ of the 226 ova recovered from the 190 treated ewes had spermatozoa attached to the zona pellucida (Table 10).

Table 10

EXP. 2, TEST 1 : NUMBER OF OVA WITH SPERMATOZOA ON THE ZONA PELLUGIDA, FROM EWES TREATED IN AUTUMN; MARGH 1967

\begin{tabular}{|c|c|c|c|c|c|c|c|c|}
\hline \multirow{2}{*}{$\begin{array}{c}\text { Ova } \\
\text { recovered }\end{array}$} & \multicolumn{6}{|c|}{ No. of spermatozoa inseminated $\left(\times 10^{6}\right)$} & \multirow{2}{*}{$\begin{array}{l}\text { Hand } \\
\text { service }\end{array}$} & \multirow{2}{*}{ Total } \\
\hline & 100 & 300 & 600 & 900 & 1200 & 1500 & & \\
\hline $\begin{array}{l}\text { Total } \\
\text { With sperm. } \\
\%\end{array}$ & $\begin{array}{c}32 \\
18 \\
56 \cdot 3\end{array}$ & $\begin{array}{c}33 \\
20 \\
60 \cdot 6\end{array}$ & $\begin{array}{c}29 \\
20 \\
68 \cdot 9\end{array}$ & $\begin{array}{c}34 \\
20 \\
58 \cdot 8\end{array}$ & $\begin{array}{c}32 \\
21 \\
65 \cdot 6\end{array}$ & $\begin{array}{c}32 \\
26 \\
81 \cdot 3\end{array}$ & $\begin{array}{c}34 \\
20 \\
58 \cdot 8\end{array}$ & $\begin{array}{c}226 \\
145 \\
64 \cdot 2\end{array}$ \\
\hline
\end{tabular}

The 226 ova were recovered from 190 ewes.

Effect of number of spermatozoa (linear) $-0.05<P<0 \cdot 10$.

There was a linear relationship between percentage of ova with attached spermatozoa and numbers of spermatozoa inseminated $(0.05<P<0 \cdot 10)$.

\section{Test 2}

Number of ewes with fertilized ova. Twenty-four of the thirty untreated ewes yielded fertilized ova as compared with twenty-three of twenty-seven treated animals $(80.0$ versus $85 \cdot 2 \%$; NS).

Nineteen of the thirty-three ova recovered from untreated animals had spermatozoa attached as compared with eighteen of thirty-two in the treated ewes $(57 \cdot 6$ versus $56 \cdot 3 \%$; NS).

\section{Test 3}

Number of spermatozoa recovered. The estimated mean numbers of spermatozoa recovered from the Fallopian tubes of treated and untreated ewes $24 \mathrm{hr}$ after the insemination of $300 \times 10^{6}$ spermatozoa were 807 and $5019(P<0.001)$. 
Text-fig. 2 shows the distribution of numbers of spermatozoa. There was evidence of a bimodal distribution in both groups of ewes. In the untreated ewes, one was centred about 768 to 1536 spermatozoa and the other about

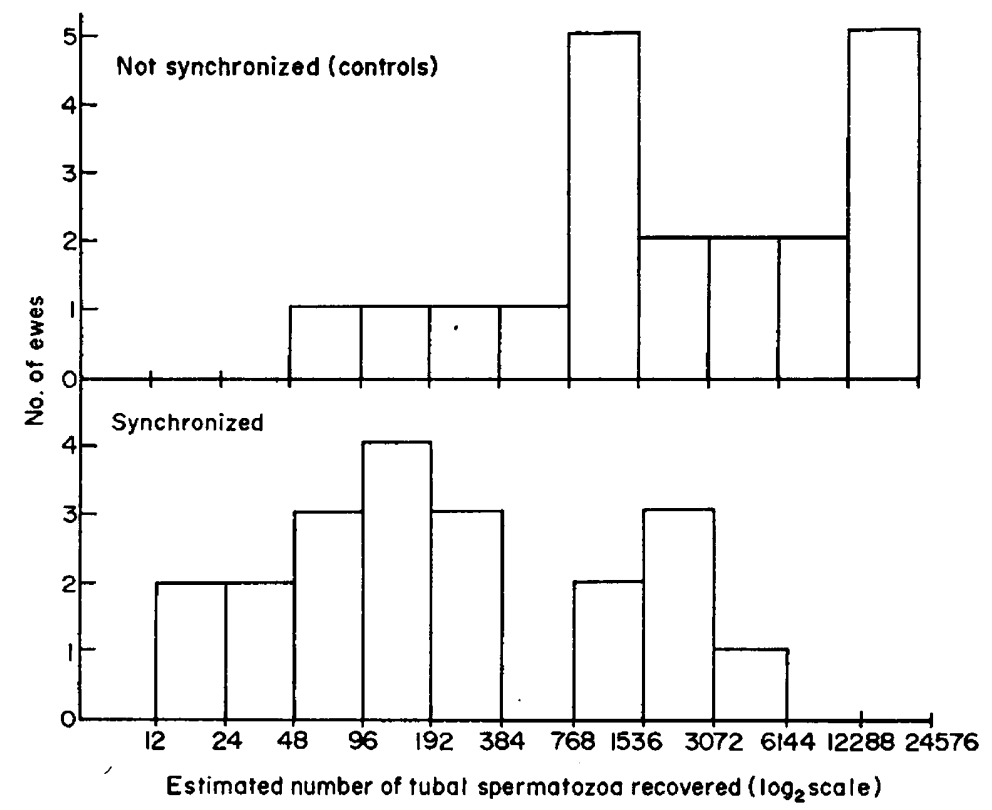

TExT-FIG. 2. Distribution curves of number of ewes which yielded tubal spermatozoa $24 \mathrm{hr}$ after artificial insemination.

12,288 to 24,576 spermatozoa. In the progestagen-treated animals, one mode was centred about 96 to 192 spermatozoa and the other about 1536 to 3072 spermatozoa. The difference in these distributions was significant $(P<0.01)$.

\section{EXPERIMENTS 1 AND 2-COMPARISON OF DATA}

Number of morphologically 'atypical' fertilized ova

Table 11 shows the distribution of ova classed into four groups. Overall, of sixty-five ova recovered from untreated ewes, thirty-eight were classed as cleaved and all appeared 'normal'. Of 575 recovered from treated ewes, 392 were classed as cleaved of which eighty-four $(21.4 \%$ of cleaved ova) were 'atypical' as illustrated in Plate 1. The incidence of such ova was similar in summer and autumn.

\section{Number of ewes which exhibited oestrus}

During the early summer, $45.7 \%$ of 5 -year-old Merino ewes exhibited oestrus, compared with $94.8 \%$ of 4 -year-olds in the autumn $(P<0.001)$.

The peak onset of oestrus following removal of the sponges during the early summer was at $72 \mathrm{hr}$, and during the autumn at $48 \mathrm{hr}$. The distribution of time of onset relative to removal of the sponges was significantly different $(P<$ $0.001)$. 

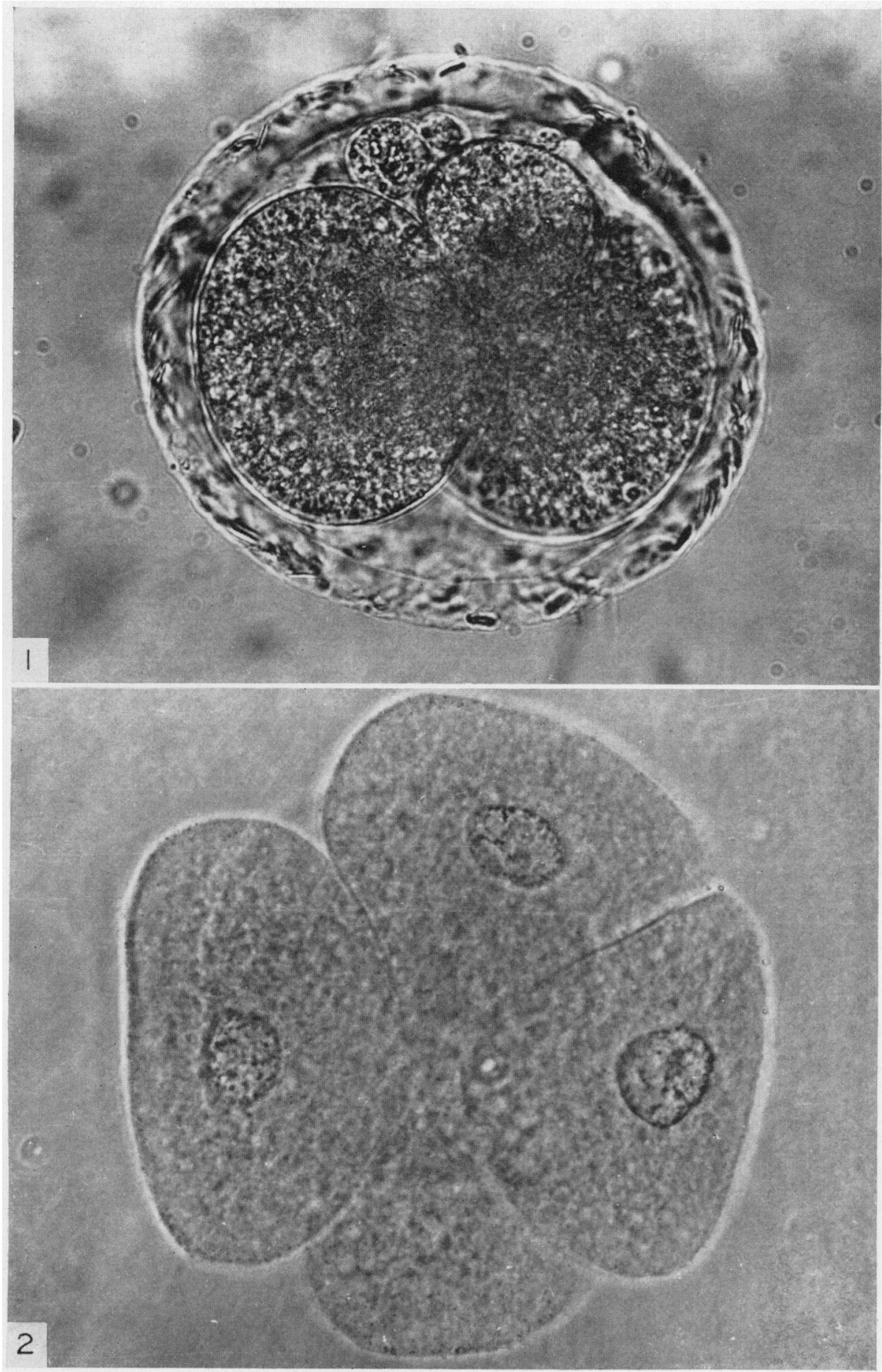

Apparenty abtormal (atypical") fertilized ora recovered from progestagen-treated ewes.

Fig. 1. I two-cell egg with anucleate fragments. $\times 360$.

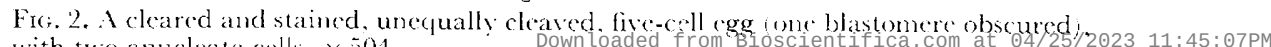
with two anucleate colls. $x 504$ 
Number of ewes yielding fertilized ova

Overall, $64.3 \%$ of the ewes mated in the summer and $83.2 \%$ of the ewes mated in the autumn yielded fertilized ova $(P<0.001)$.

Of the ewes inseminated with from 300 to $1500\left(\times 10^{6}\right)$ Merino spermatozoa, $73.3 \%$ were fertilized in the summer as compared with $83.7 \%$ in the autumn

TABLE 11

EXPS I AND 2: THE GLASSIFICATION OF OVA REGOVERED FROM UNTREATED AND TREATED EWES

\begin{tabular}{|c|c|c|c|c|c|c|c|c|}
\hline \multirow{4}{*}{ Classification of ova } & \multicolumn{8}{|c|}{ No. of ova recovered } \\
\hline & \multicolumn{4}{|c|}{ Experiment 1-Summer } & \multicolumn{4}{|c|}{ Experiment 2-Autumn } \\
\hline & \multicolumn{2}{|c|}{ Untreated ewes } & \multicolumn{2}{|c|}{ Treated ewes } & \multicolumn{2}{|c|}{ Untreated ewes } & \multicolumn{2}{|c|}{ Treated ewes } \\
\hline & No. & $\%$ & No. & $\%$ & No. & $\%$ & No. & $\%$ \\
\hline $\begin{array}{l}\text { Cleaved-'normal' } \\
\text { 'atypical'* } \\
\text { Fractured } \\
\text { Non-fertilized }\end{array}$ & $\begin{array}{r}13 \\
0 \\
0 \\
19\end{array}$ & $\begin{array}{r}40 \cdot 6 \\
0.0 \\
0 \cdot 0 \\
59 \cdot 4\end{array}$ & $\begin{array}{r}169 \\
46 \\
4 \\
130\end{array}$ & $\begin{array}{r}48 \cdot 4 \\
13 \cdot 2 \\
1 \cdot 1 \\
37 \cdot 3\end{array}$ & $\begin{array}{r}25 \\
0 \\
1 \\
7\end{array}$ & $\begin{array}{r}75 \cdot 8 \\
0 \cdot 0 \\
3 \cdot 0 \\
21 \cdot 2\end{array}$ & $\begin{array}{r}139 \\
38 \\
8 \\
41\end{array}$ & $\begin{array}{r}61 \cdot 5 \\
16 \cdot 8 \\
3 \cdot 5 \\
18 \cdot 2\end{array}$ \\
\hline Total & 32 & $100 \cdot 0$ & 349 & $100 \cdot 0$ & 33 & $100 \cdot 0$ & 226 & $100 \cdot 0$ \\
\hline
\end{tabular}

All untreated ewes were artificially inseminated. Data for AI and natural mating pooled for progestagen-treated ewes.

* 'Atypical' ova showed unequal cleavage or apparent fragmentation.

$(P<0.05)$. There was no significant effect of number of spermatozoa and no interaction. There was no significant difference between ewes hand mated to the Merino rams in the two seasons (86.7\% summer versus $78.6 \%$ autumn).

\section{Number of ova with spermatozoa on the zona pellucida}

Overall, $40.7 \%$ of the ewes mated in the summer and $64.2 \%$ of the ewes mated in the autumn yielded ova with spermatozoa attached $(P<0.001)$.

Of the ewes inseminated with from 300 to $1500\left(\times 10^{6}\right)$ Merino spermatozoa, $49.7 \%$ yielded ova with spermatozoa attached in the summer, as compared with $66.9 \%$ in the autumn $(P<0.01)$. The increase with increasing number of spermatozoa inseminated occurred in both seasons, so there was no interaction. There was no seasonal difference between ewes hand-mated to Merino rams.

\section{DISGUSSION}

These experiments show that the stage of the breeding season has an important influence on the response of ewes to intravaginal treatment with progestagen. This is manifested by effects upon the proportion of ewes in oestrus, the time of onset of oestrus, the proportion of ova fertilized and, particularly where British breed rams are used, the number of spermatozoa required for optimum chances of fertilization.

It is important to recognize the confounding effects resulting from the introduction of rams and the cessation of progestagen treatment on ovulation 
and oestrus early in the breeding season. Thus, the percentage of progestagentreated ewes detected in oestrus within 5 days when mated on cessation of treatment was $45 \cdot 7$. The percentages of untreated ewes were 47.5 for ewes previously exposed to rams ('teased') and 30.0 for ewes not exposed. This latter difference is significant and confirms the observation of Cunningham, Deas \& Fitzsimmons (1967) concerning the necessity for adequate control animals in any evaluation of methods available for the advancement of the breeding season.

By contrast with the $45.7 \%$ of treated ewes observed in oestrus in the summer, $94.8 \%$ were in oestrus in the autumn. They also came into oestrus earlier in the autumn which, by analogy with the observations of Scaramuzzi (1968) and Fletcher (1969) on spayed ewes, suggests a greater production of oestrogen resulting in earlier onset and a longer duration of oestrus; that is, oestrus is of greater intensity than in the summer.

These effects on the oestrous response are carried further into the subsequent process of fertilization. It is well established (Quinlivan \& Robinson, 1967, 1969) that the ewe treated with intravaginal progestagen has a pattern of transport and survival of spermatozoa which differs from that in the normal ewe, resulting in lower numbers of spermatozoa in the Fallopian tubes and susceptibility to failure of fertilization. This susceptibility is greater in the summer than in the autumn, and is further aggravated if British breed rams (Border Leicester) are used in the summer. Semen of the latter, as compared with that of Merino rams, resulted in markedly fewer fertilized ova, fewer with spermatozoa attached, and a much greater dependence on large numbers of spermatozoa for fertilization. The deficiency of the Border Leicester semen was not confined to the treated ewe-it applied also to the untreated-and it is not a function of artificial insemination; hand served ewes were also infertile.

In view of the linear increase in fertilization rates in summer with increase in numbers of spermatozoa, and also the breed difference, it is concluded that varied numbers of spermatozoa are required for maximum fertility at different seasons of the year and with different breeds. In this experiment in the summer, $1500 \times 10^{6}$ Border Leicester spermatozoa were required to provide $65 \%$ fertilization, while $600 \times 10^{6}$ Merino spermatozoa provided $77 \%$, and there was no significant increase thereafter with increasing numbers. In the autumn, there was no advantage in using more than $100 \times 10^{6}$ Merino spermatozoa (mean $83 \%$ fertilization). While these data refer specifically to progestagen-treated ewes, they need to be considered in evaluating the numbers of spermatozoa required for maximum chances of conception using different breeds of rams at different times of the year, factors not usually considered in estimates of the minimum numbers of spermatozoa required for artificial insemination (Emmens \& Robinson, 1962; Salamon, 1962).

The problem of poor fertilization in treated ewes, associated with an abnormal pattern of transport and survival of spermatozoa (Quinlivan \& Robinson, $1967,1969)$ appears much more serious very early in the breeding season (December-summer) than in the middle of the season (March-autumn). In the autumn, the problem is marginal; $83.2 \%$ of recovered ova were fertilized, only 7 to $12 \%$ below the figure commonly quoted for normal ewes. In the 
summer, the figure is somewhat lower $(75.6 \%$ for Merino rams, $47.5 \%$ for Border Leicesters). In the latter case, the problem is partly alleviated by massive sperm numbers but even with numbers as high as $1500 \times 10^{6}$, only $65 \%$ of ova were fertilized with Border Leicester semen and $83 \%$ with Merino.

Evidence for the existence of a problem of transport and survival of spermatozoa, which can only partly be overcome by the use of excessively large numbers, is provided by the data for number of ova with attached spermatozoa. Very few ova $(23 \%)$ from ewes inseminated in summer with Border Leicester semen had spermatozoa attached, while those inseminated with Merino semen showed a linear increase from 27 to $62 \%$ of such ova with increasing numbers of spermatozoa inseminated. In the autumn, the mean number of such ova was much higher $(64 \%)$ and again there was a positive association with numbers of spermatozoa inseminated. These observations confirm the conclusion of Quinlivan \& Robinson (1967) that the presence of ova with attached spermatozoa serves as a useful guide to the effectiveness of transport and survival of spermatozoa.

It was not possible to assess the potential capacity for development of the 'atypical' ova recovered from the treated ewes. Recently, Killeen (1969) has shown that such eggs transferred to donor ewes may develop normally. There is, however, the distinct possibility that such ova are the result of late fertilization. Counts of the numbers of spermatozoa in the Fallopian tubes $24 \mathrm{hr}$ after insemination in the autumn (Exp. 2) showed differences between progestagentreated and untreated ewes. Earlier, Quinlivan \& Robinson (1967) had shown that maximum accumulation of tubal spermatozoa in normal ewes is $24 \mathrm{hr}$ after insemination and of treated ewes, $36 \mathrm{hr}$. Hence, there may be some difference between treated and untreated ewes in the time, relative to ovulation, at which penetration by a spermatozoon occurs.

Robinson (1970) has shown a pattern of seasonal variation in response to intravaginal progestagen treatment, similar to that reported here. In the summer, the incidence of ovulation without oestrus ('silent' heats) is high, the onset of oestrus relative to cessation of treatment is late, and the pregnancy rate following two inseminations 8 to $10 \mathrm{hr}$ apart is low (52\%). In the autumn, most ewes exhibit oestrus with ovulation, the onset of oestrus is early and the pregnancy rate is high $(80 \%)$. Data presented in this paper conform to this pattern for each parameter and show that seasonal differences in fertility can be accounted for by differences in fertilization rates. These may be affected by breed of ram and to some extent by the numbers of spermatozoa inseminated at the particular season. The contribution to failure of pregnancy of early mortality of the 'atypical' ova is an open question.

\section{AGKNOWLEDGMENTS}

The author is indebted to Professor T. J. Robinson for his assistance in the preparation of the manuscript. Grateful acknowledgment is made to the Trustees and Manager of the McCaughey Memorial Institute, Jerilderie, for the provision of sheep and facilities, and to Mr I. D. Killeen, Mr R. J. Maddy, Mr A. D. Barnes, Mr J. F. Smith, Miss B. D. Matthews and Miss M. A. 
Hutchins for technical assistance. Estimates of residual Cronolone were made on the sponges from Exps 1 and 2 by Mrs J. Morgan, Department of Organic Chemistry, University of Sydney.

The experimental materials were generously supplied by G. D. Searle and Co. (Aust.), Sydney, and the programme received financial support from the Australian Research Grants Committee.

\section{REFERENGES}

Gunningham, J. M. M., Deas, D. W. \& Fitzsimmons, J. (1967) Synchronization of oestrus in ewes. Vet. Rec. 80, 590.

Emmens, C. W. \& Robinson, T. J. (1962) Artificial insemination in the sheep. In: Semen of Animals and Artificial Insemination, Chap. 12. Ed. G. P. Maule. Commonw. Agric. Bureaux, Edinburgh.

FLETcher, I. C. (1969) Interrelationships between hormones, behaviour and fertility in sheep. Ph.D. thesis, University of Sydney.

Hunter, G. L., Adams, G. E. \& Rowson, L. E. (1955) Inter-breed ovum transfer in sheep. F. agric. Sci., Camb. 46, 143.

KILLEEN, I. D. (1969) Studies in fertilization and early development of the ovine ovum. Ph.D. thesis, University of Sydney.

Morgan, J., LACK, R. E. \& RoBinson, T. J. (1967) The rate of absorption of SC-9880 from impregnated sponges inserted intravaginally in cyclic crossbred ewes. In: The Control of the Ovarian Cycle in the Sheep, p. 195. Ed. T. J. Robinson. Sydney University Press.

Quinlivan, T. D. \& Robinson, T. J. (1967) The number of spermatozoa in the Fallopian tubes of ewes at intervals after artificial insemination following withdrawal of SC-9880 impregnated intravaginal sponges. In: The Control of the Ovarian Cycle in the Sheep, p. 177. Ed. T. J. Robinson. Sydney University Press.

QuinLIVAN, T. D. \& Robinson, T. J. (1969) The numbers of spermatozoa in the genital tract of the ewe at intervals after artificial insemination following withdrawal of fluoro-progestagen impregnated intravaginal sponges. F. Reprod, Fert. 19, 73.

RoBinson, T. J. (1965) Use of progestagen-impregnated sponges inserted intravaginally or subcutaneously for the control of the oestrous cycle in the sheep. Nature, Lond. 206, 39.

RoBisson, T. J. (1967) The control of the ovarian cycle in the sheep. Sydney University Press.

Robinson, T. J. (1971) The seasonal nature of reproductive phenomena in the sheep. II. Variation in fertility following synchronization of oestrus. F. Reprod. Fert. (In press).

Salamon, S. (1962) Studies on the artificial insemination of Merino sheep. III. The effect of frequent ejaculation on semen characteristics and fertilizing capacity. Aust. 7. agric. Sci. 13, 1137.

Scaramuzzi, R. J. (1968) Studies in reproductive physiology of the ewe. Ph.D. thesis, University of Sydney.

Srelton, J. N. (1965) Identification of progestagens of high activity for the control of the oestrous cycle in the sheep. Nature, Lond. 206, 156. 